\title{
Title
}

\section{The radiopacity and antimicrobial properties of different radiopaque double antibiotic pastes used in regenerative endodontics}

\author{
Authors \\ Rohan Verma, DDS*; Benjamin I. Fischer, DDS*; Richard L. Gregory, PhD* and \\ Ghaeth H. Yassen, BDS, MSD, PhD** \\ * Department of Biomedical and Applied Sciences, Indiana University School of \\ Dentistry, Indianapolis, Indiana. \\ ¥Department of Endodontics, Case School of Dental Medicine, Cleveland, Ohio
}

Corresponding author:

Ghaeth H. Yassen

Department of Endodontics

Case School of Dental Medicine

2124 Cornell Rd.

Cleveland, $\mathrm{OH} 44106$

Tel: +1-317-437-2240

E-mail address:gyassen@umail.iu.edu

This is the author's manuscript of the article published in final edited form as:

Verma, R., Fischer, B. I., Gregory, R. L., \& Yassen, G. H. (2018). The Radiopacity and Antimicrobial Properties of Different Radiopaque Double Antibiotic Pastes Used in Regenerative Endodontics. Journal of Endodontics, 44(9), 1376-1380. https://doi.org/10.1016/j.joen.2018.06.010 


\begin{abstract}
Introduction: We evaluated the radiopacity and the antibacterial properties of various concentrations of double antibiotic paste (DAP) containing barium sulfate $\left(\mathrm{BaSO}_{4}\right)$ or zirconium oxide $\left(\mathrm{ZrO}_{2}\right)$ radiopaque agents for both direct and residual antibacterial effects. Methods: The radiopacity of 1,10 and $25 \mathrm{mg} / \mathrm{mL}$ of DAP containing $30 \%$ (w/v) of $\mathrm{BaSO}_{4}$ or $\mathrm{ZrO}_{2}$, DAP-free radiopaque pastes and commercially available radiopaque calcium hydroxide $\left(\mathrm{Ca}(\mathrm{OH})_{2}\right)$ were evaluated according to ISO $6876 / 2001$ with slight modifications ( $\mathrm{n}=6$ per group). In order to test for direct antibacterial effects dentin samples $(n=70)$ infected anaerobically for 3 weeks with bacterial biofilms obtained from root canals of an immature tooth with pulpal necrosis were treated with similar experimental pastes or received no treatment $(n=7)$. After one week, the pastes were rinsed-off and biofilm disruption assays were conducted. In order to demonstrate residual effects sterile dentin samples $(n=70)$ were pretreated for 1 week with the same pastes $(n=7)$. The pastes were rinsed off, samples were immersed in PBS for 24 hours and infected anaerobically with the same bacterial biofilm mentioned earlier for 3 weeks before conducting biofilm disruption assays. Sterile dentin blocks were used in both antibacterial analyses as negative control groups ( $\mathrm{n}=14)$. Wilcoxon Rank Sum tests were used for statistical analyses. Results: No tested concentrations of $\mathrm{BrSO}_{4}-\mathrm{DAP}$ and $\mathrm{ZrO}_{2}-\mathrm{DAP}$ demonstrated significant differences from $\mathrm{Ca}(\mathrm{OH})_{2}$ in radiopacity. However, all tested concentrations of $\mathrm{BrSO}_{4}-\mathrm{DAP}$ and $\mathrm{ZrO}_{2}-\mathrm{DAP}$ as well as $\mathrm{Ca}(\mathrm{OH})_{2}$ exhibited significant direct antibacterial effects. $\mathrm{ZrO}_{2}-\mathrm{DAP}$ at 1 $\mathrm{mg} / \mathrm{mL}$ and $\mathrm{Ca}(\mathrm{OH})_{2}$ did not demonstrate significant residual antibacterial effects. Conclusions: $\mathrm{BrSO}_{4}-\mathrm{DAP}$ at $1 \mathrm{mg} / \mathrm{mL}$ provided significantly superior residual antibacterial effects and comparable radiopacity to the commercially available $\mathrm{Ca}(\mathrm{OH})_{2}$.
\end{abstract}


Keywords: Biofilms, Endodontic regeneration, Double antibiotic paste, Barium sulfate, Immature tooth, Zirconium oxide.

\section{Introduction}

The introduction of endodontic regeneration procedures has rejuvenated the use of various antibiotic mixtures as intracanal medicaments. Recent in vitro studies have found that intracanal antibiotic medicaments such as triple (TAP) or double (DAP) antibiotic paste may offer superior root canal disinfection in comparison to traditional calcium hydroxide $\left(\mathrm{Ca}(\mathrm{OH})_{2}\right)$ intracanal medicament $(1,2)$. However, unlike $\mathrm{Ca}(\mathrm{OH})_{2}$, clinically used concentrations (500$1000 \mathrm{mg} / \mathrm{mL}$ ) of these antibiotic mixtures were found to exert cytotoxic effects on stem cells from apical papillae $(3,4)$, dental pulp stem cells (5), and dental pulp fibroblast (6). Therefore, evidence-based recommendations suggested the use of $\mathrm{Ca}(\mathrm{OH})_{2}$ or low concentrations on DAP or TAP ranging between $0.1-1 \mathrm{mg} / \mathrm{mL}$ in an attempt to provide an efficient antimicrobial medicament without jeopardizing the fate of pluripotent stem cells within the root canal system (7).

The inability of these antibiotic medicaments to be visualized radiographically may offer a challenging aspect to clinicians in term of insuring the satisfactory application of the medicaments. Indeed, the use of radiopaque intracanal medicaments can be of particular importance during endodontic regeneration due to the presence of large blunder buss apices of immature teeth with necrotic pulps. Therefore, over or under application of non-radiopaque antibiotic medicaments can easily go unnoticed, which may lead to suboptimal root canal disinfection during regenerative endodontics. Radiopaque components are usually added to endodontic materials (cements, pastes, sealers, and obturating materials) to provide radiopacity that can help in determining the exact location of the root canal material in the root canal system 
as well as improving the ability of the material to localize anatomical structures within the root canal system. The radiocontrast agents commonly used in endodontic materials are insoluble salts of heavy metals such as barium, zirconium and bismuth. The aim of this study was to introduce two types of radiopaque DAP and investigate the direct and residual antibacterial effects of these radiopaque antibiotic medicaments.

\section{Materials and methods}

\section{Preparation of radiopaque DAP}

Two radiopaque materials, namely barium sulfate $\left(\mathrm{BaSO}_{4}\right)$ and zirconium oxide $\left(\mathrm{ZrO}_{2}\right)$ were selected for this study. Various concentrations of DAP containing the two radiopaque agents were prepared as described in previous studies $(8,9)$ with a modification to incorporate the radiopaque materials. In summary, 10, 100, and $250 \mathrm{mg}$ of equal portions of metronidazole and ciprofloxacin (Champs Pharmacy, San Antonio, TX) were independently dissolved in $10 \mathrm{~mL}$ of sterile water to form 1,10 and $25 \mathrm{mg} / \mathrm{mL}$ of DAP solutions, respectively. Then, $3 \mathrm{~g}$ of barium sulfate (Reagent Plus, Sigma-Aldrich, St. Louis, MO) or zirconium oxide (5 um powder; Sigma) was gradually incorporated into each DAP solution with vigorous stirring to form a $30 \%$ radiopaque DAP slurry composed of $30 \%(\mathrm{w} / \mathrm{v})$ of each radiopaque material. Thereafter, $0.7 \mathrm{~g}$ of methylcellulose powder (Methocel 60 HG, Sigma-Aldrich, St. Louis, MO) was gradually dissolved into each DAP slurry at room temperature to create a pasty consistency of DAP. Finally, each radiopaque DAP was centrifuged for 15 minutes at $7000 \mathrm{rpm}$ to form a bubble-free homogenous injectable paste with 1, 10 and $25 \mathrm{mg} / \mathrm{mL}$ of DAP $\left(\mathrm{BrSO}_{4}-\mathrm{DAP}\right.$ or $\left.\mathrm{ZrO}_{2}-\mathrm{DAP}\right)$. Furthermore, DAP-free radiopaque placebo pastes were also prepared as described earlier. The percentage of radiopaque agents $(30 \% \mathrm{w} / \mathrm{v})$ was selected based on pilot studies that examined 
$20-40 \%$ of both radiopaque agents in $5 \%$ increments compared to a commercially available radiopaque $\mathrm{Ca}(\mathrm{OH})_{2}$ intracanal medicament (UltraCal XS, Ultradent, South Jordan, UT). Assessment of radiopacity

The radiopacity of various concentrations of $\mathrm{BrSO}_{4}$-DAP $(1,10,25 \mathrm{mg} / \mathrm{mL}), \mathrm{ZrO}_{2}$-DAP $(1,10,25 \mathrm{mg} / \mathrm{mL})$, the two DAP-free placebo pastes, and the commercially available radiopaque calcium hydroxide medicament (UltraCal) were evaluated according to ISO 6876:2012 (10) with slight modifications. Briefly, disk-shaped plastic molds (internal diameter of 1 and $10 \mathrm{~mm}$ in thickness) were positioned on occlusal radiograph films (Insight-Kodak Comp, Rochester, NY) and filled with the tested pastes $(\mathrm{n}=6)$. Radiographs of the pastes along with an aluminum step wedge with variable thickness (from 1 to $5 \mathrm{~mm}$, in $1 \mathrm{~mm}$ increments) were taken using a singlephase dental X-ray unit (Heliodent DS, Sirona Dental, Inc., Charlotte, NC) with $65 \mathrm{kV}$ and a distance of $30 \mathrm{~cm}$. The radiographic films were processed using an automatic processor. Finally, the densities of the image of the pastes were compared to that of the different thickness of the aluminum step wedge using a densitometer (X-Rite, model 301, X-Rite, Grand Rapids, MI) and the radiopacity equivalent of each sample was expressed in millimeter of aluminum (mm Al).

\section{Dentin sample preparation}

Extracted intact human teeth were used to prepare radicular dentin samples $\left(4 \times 4 \times 2 \mathrm{~mm}^{3}\right)$ according to a standardized protocol. Briefly, a low speed diamond saw under constant water irrigation was used to obtain dentin samples with the standardized dimensions. The samples were polished sequentially using abrasive papers (500-2400 grit; Struers, Cleveland, $\mathrm{OH}$ ) and a Roto Pol 31 polishing unit (Struers). The samples were sequentially irrigated with $1.5 \% \mathrm{NaOCl}$, double distilled water and 17\% EDTA (4 minutes each) to open dentin tubules and remove the 
smear layer (11). All samples were gas sterilized using ethylene oxide and maintained at $100 \%$ humidity and $4^{\circ} \mathrm{C}$ until used.

\section{Collection of bacterial isolate}

An institutional review board approval was obtained (IRB \# 1510640949) to collect a clinical bacterial isolate from an infected root canal of an immatue tooth that was indicated for endodontic regenerative treatment. The selected subject was healthy and had not used antibiotics for 6 months. Both the subject and his parent signed an informed assent and consent before collection of the bacterial isolate. The bacterial isolate was obtained according to a standardized protocol detailed in previous studies $(2,12)$, anaerobically incubated in brain heart infusion broth supplemented with $5 \mathrm{~g} / \mathrm{L}$ of yeast extract $(\mathrm{BHI}-\mathrm{YE})$ at $37^{\circ} \mathrm{C}$ for 48 hours, and frozen at $-80^{\circ} \mathrm{C}$ until used.

\section{Direct antibacterial effects of radiopaque DAP}

Sterile dentin samples $(\mathrm{n}=70)$ were individually inserted into wells of sterile 96-well microtiter plates (FisherBrand, Fischer Scientific) with the pulpal sides oriented outward. The dentin samples were infected with $10 \mu \mathrm{L}$ of an overnight culture $\left(1 \times 10^{5} \mathrm{CFU} / \mathrm{mL}\right)$ of the biofilm bacteria obtained from an immature tooth with pulpal necrosis and $190 \mu \mathrm{L}$ of fresh BHIYE added. The infected dentin samples were incubated for 3 weeks anaerobically with weekly replacement of BHI-YE growth media. The weekly replacement of growth media was aimed to maintain the original taxa of the clinical isolates by limiting the nutritional supply as recommended in previous publications $(13,14)$. Three additional dentin samples were infected with the same biofilm bacteria and viewed under scanning electron microscopy (JEOL 7800F, Peabody, MA). 
After three weeks, the infected dentin samples were randomized into 10 experimental groups $(\mathrm{n}=7)$ and treated for one week at $37^{\circ} \mathrm{C}$ with $\mathrm{BrSO}_{4}$-DAP $(1,10,25 \mathrm{mg} / \mathrm{mL}), \mathrm{ZrO}_{2}$-DAP $(1,10,25 \mathrm{mg} / \mathrm{mL}), \mathrm{BrSO}_{4}-\mathrm{Placebo}, \mathrm{ZrO}_{2}-\mathrm{Placebo}, \mathrm{Ca}(\mathrm{OH})_{2}(\mathrm{UltraCal})$ or sterile water. All infected dentin samples were treated for 1 week at $37^{\circ} \mathrm{C}$ and $100 \%$ humidity. A bacteria-free sterile dentin group $(\mathrm{n}=7)$ was also utilized in this experiment as a negative group to exclude the presence of bacterial contamination though the course of the experiment. The dentin samples in the negative control received fresh BHI-YE and was incubated anaerobically with the rest of the samples for 3 weeks with weekly replacement of BHI-YE.

After treatment, each sample was gently irrigated with $3 \mathrm{~mL}$ of sterile water for $1 \mathrm{~min}$ to rinse off the treatment pastes and each dentin sample was subjected to a biofilm disruption assay as described in earlier studies $(15,16)$. Briefly, each dentin sample was placed into a sterile test tube containing $2 \mathrm{~mL}$ of sterile water. Each sample was sonicated and vortexed (30 s each) to dislodge the biofilms. The obtained biofilms were diluted, spiral plated on blood agar plates, incubated anaerobically for $24 \mathrm{~h}$, and CFUs/mL were counted using an automated colony counter (Synbiosis, Inc, Frederick, MD, USA).

\section{Residual antibacterial effects of radiopaque DAP}

Additional sterilized dentin samples (70) were placed in 96-well microtiter plates in order to be pretreated for 1 week with the same ten experimental groups described earlier $(\mathrm{n}=10)$. After treatment, the pastes were washed off from the dentin samples using sterile saline followed by a $1 \mathrm{~min}$ irrigation with $5 \mathrm{~mL}$ of 17\% EDTA. Dentin samples were independently immersed in $200 \mathrm{~mL}$ of sterile phosphate buffered saline (PBS) and stored at $37^{\circ} \mathrm{C}$ for $24 \mathrm{~h}$. After immersion, dentin samples were infected with an overnight culture of the biofilm bacteria obtained from the immature tooth with pulpal necrosis discussed earlier $(\mathrm{n}=7)$. The bacterial biofilms were grown 
anaerobically for 3 weeks as described earlier. Additional non-infected sterile dentin samples $(\mathrm{n}=7)$ were used as a negative control throughout this experiment. After the incubation period, all samples were subjected to biofilm disruption assays and $\mathrm{CFUs} / \mathrm{mL}$ were quantified.

\section{Statistical analyses}

Wilcoxon Rank Sum tests were used to compare the radiopacity, and direct and residual antibacterial effects of all experimental groups $(\alpha=0.05)$.

\section{Results}

\section{Assessment of radiopacity}

Both $\mathrm{BrSO}_{4}$-DAP and $\mathrm{ZrO}_{2}$-DAP at the three tested concentrations $(1,10,25 \mathrm{mg} / \mathrm{mL})$ did not demonstrate a significant difference from calcium hydroxide (the commercial control) in radiopacity (Figure 1). However, the $\mathrm{ZrO}_{2}-\mathrm{Placebo}$ samples demonstrated significantly higher $(\mathrm{P}<0.01)$ radiopacity than the $\mathrm{BrSO}_{4}-\mathrm{DAP}$ (all concentrations), $\mathrm{Ca}(\mathrm{OH})_{2}$ and $\mathrm{ZrO}_{2}-\mathrm{DAP}$ at 25 $\mathrm{mg} / \mathrm{mL}$ groups. $\mathrm{ZrO}_{2}$-DAP at 1,10 and $25 \mathrm{mg} / \mathrm{mL}$ exhibited significantly higher radiopacity than $\mathrm{BrSO}_{4}-\mathrm{DAP}$ at 1,10 and $25 \mathrm{mg} / \mathrm{mL}$, respectively $(\mathrm{P}<0.01)$.

\section{Assessment of direct antibacterial effects}

$\mathrm{BrSO}_{4}-\mathrm{DAP}$ and $\mathrm{ZrO}_{2}$-DAP at the three tested concentrations $(1,10,25 \mathrm{mg} / \mathrm{mL})$ as well as $\mathrm{Ca}(\mathrm{OH})_{2}$ demonstrated significant direct antibacterial effects in comparison to placebo pastes and the no treatment control groups $(\mathrm{P}<0.001)$ (Table 1). Furthermore, $\mathrm{BrSO}_{4}-\mathrm{DAP}$ at all tested concentrations and $\mathrm{ZrO}_{2}$-DAP at 10 and $25 \mathrm{mg} / \mathrm{mL}$ demonstrated significantly higher antibacterial effects in comparisons to $\mathrm{BrSO}_{4}-\mathrm{DAP}$ at $1 \mathrm{mg} / \mathrm{mL}(\mathrm{P}<0.01)$. No bacterial growth was detected in the negative (sterile) control group. SEM images taken at various magnifications demonstrated thick heterogenic biofilm structures covering most of the pulpal surface of the dentin (Figures 2A and 2B). 


\section{Assessment of residual antibacterial effects}

$\mathrm{BrSO}_{4}-\mathrm{DAP}$ at all tested concentrations as well as $\mathrm{ZrO}_{2}-\mathrm{DAP}$ at 10 and $25 \mathrm{mg} / \mathrm{mL}$ demonstrated significantly higher residual antibacterial effects in comparison to $\mathrm{ZrO}_{2}-\mathrm{DAP}$ at 1 $\mathrm{mg} / \mathrm{mL}, \mathrm{Ca}(\mathrm{OH})_{2}$, placebo pastes and the no treatment control groups $(\mathrm{P}<0.01)$ (Table 1$)$. However, no significant differences were found between $\mathrm{ZrO}_{2}-\mathrm{DAP}$ at $1 \mathrm{mg} / \mathrm{mL}, \mathrm{Ca}(\mathrm{OH})_{2}$, placebo pastes and the no treatment control groups. Additionally, the negative (sterile) control group did not demonstrate any bacterial growth.

\section{Discussion}

Commercially available antibiotic intracanal medicaments such as Ledermix and Odontopaste are available. However, these medicaments contain relatively high concentrations of antibiotic and are not radiopaque, which limits their use. Recent studies introduced an injectable controlled low concentration of DAP loaded into a biocompatible hydrogel $(2,15)$. However, one of the limitations of these injectable medication is their lack of radiopaque properties. Since there is no ISO standard for testing intracanal medicaments, the radiopacity testing protocol used in the current study was adapted from the ISO 6876; 2012 standards designed for dental root canal sealing materials with a slight modification. The tested medicaments in our study were radiographed immediately after their application into the plastic molds rather than waiting for $24 \mathrm{~h}$ as recommended by ISO since these medicaments are not expected to set like root canal sealers.

The current study introduced two different types of radiopaque DAP with controlled concentrations using FDA approved radiocontrast agents $\left(\mathrm{BrSO}_{4}\right.$ and $\left.\mathrm{ZrO}_{2}\right) . \mathrm{BrSO}_{4}$ is a commonly used radiopaque material in $\mathrm{Ca}(\mathrm{OH})_{2}$-based root canal medicaments and zinc oxideeugenol-based root canal sealers. $\mathrm{ZrO}_{2}$ is also a commonly used radiopaque agent in commercial 
available bioceramic root canal sealers/cements such as Endosquence BC sealers as well as in Biodentine. Furthermore, both radiopaque materials were suggested to be biocompatible $(17,18)$ with minimum discoloration potential $(19,20)$. The current study demonstrated that both $\mathrm{ZrO}_{2}$ DAP and $\mathrm{BrSO}_{4}-\mathrm{DAP}$ at all tested concentrations did not significantly different from $\mathrm{Ca}(\mathrm{OH})_{2}$ (UltralCal). However, the tested concentrations of $\mathrm{ZrO}_{2}$-DAP $(1,10$ and $25 \mathrm{mg} / \mathrm{mL})$ demonstrated significantly higher radiopacity than the similarly tested concentrations of $\mathrm{BrSO}_{4}$ DAP. The commercially available radiopaque $\mathrm{Ca}(\mathrm{OH})_{2}$ was used in this study because it is one of the most commonly used intracanal medicaments in the United States and has been used in multiple endodontic regeneration studies $(3,4,9)$.

Our study demonstrated that $\mathrm{ZrO}_{2}$-DAP and $\mathrm{BrSO}_{4}-\mathrm{DAP}$ as low as $1 \mathrm{mg} / \mathrm{mL}$ caused significant reduction in bacterial biofilm in comparison to the radiopaque DAP-free placebo pastes. This indicates that the addition of these radiopaque agents at 30\% (w/v) did not interfere with the direct antibacterial properties of DAP at the tested concentrations $(1-25 \mathrm{mg} / \mathrm{mL})$. This agreed with recent studies which found significant direct antibacterial effects of $1 \mathrm{mg} / \mathrm{mL}$ of nonradiopaque DAP against bacterial biofilm obtained from clinical isolates (2) as well as bacterial biofilm of Enterococcus faecalis (15). Our study also demonstrated that $\mathrm{BrSO}_{4}$-DAP at $1 \mathrm{mg} / \mathrm{mL}$ exhibited significantly higher direct antibacterial effects than $\mathrm{ZrO}_{2}-\mathrm{DAP}$ at $1 \mathrm{mg} / \mathrm{mL}$. It is worth noting that $1 \mathrm{mg} / \mathrm{mL}$ of DAP was selected in this study as the minimum tested concentration because it is the currently recommended concentration of intracanal antibiotic medicaments for endodontic regeneration (7).

Our study also found that $\mathrm{BrSO}_{4}-\mathrm{DAP}$ at $1 \mathrm{mg} / \mathrm{mL}$ exhibited significant residual antibacterial effects. On the other hand, $\mathrm{ZrO}_{2}$-DAP at $1 \mathrm{mg} / \mathrm{mL}$ as well as $\mathrm{Ca}(\mathrm{OH})_{2}$ did not exhibit any significant residual antibacterial effects. This might suggest that $\mathrm{ZrO}_{2}$ can interfere 
with residual antibacterial effects of the $1 \mathrm{mg} / \mathrm{mL}$ DAP. Therefore, higher concentration of DAP may be needed if $\mathrm{ZrO}_{2}$ is to be used as radiopaque agent as $\mathrm{ZrO}_{2}$-DAP at $10 \mathrm{mg} / \mathrm{mL}$ demonstrated significant residual antibacterial effects. The collective finding of direct and residual antibacterial experiments conducted in this study indicates that $\mathrm{BrSO}_{4}-\mathrm{DAP}$ exhibited significantly superior antibacterial properties than $\mathrm{ZrO}_{2}-\mathrm{DAP}$ at $1 \mathrm{mg} / \mathrm{mL}$. One of the main advantages of using antibiotic-containing intracanal medicaments over $\mathrm{Ca}(\mathrm{OH})_{2}$ during regenerative endodontic is the residual ability of these antibiotics to bind to dentin matrix and extend the antimicrobial properties within the root canal system even after their removal $(1,2)$. Recent in vitro studies, as in this study, have found that $\mathrm{Ca}(\mathrm{OH})_{2}$ cannot provide any residual antibacterial properties after its removal from radicular dentin $(1,2)$. These laboratory findings are in support of clinical studies that found bacterial regrowth after removal of a $\mathrm{Ca}(\mathrm{OH})_{2}$ intracanal medicament $(21,22)$.

In the current study, a clinical isolate obtained from an immature tooth with necrotic pulp was used to establish the bacterial biofilm in an attempt to create a more resistant in vitro model. Bacterial biofilms from immature teeth were found to be more resistant to antimicrobials compared to bacterial biofilms from mature teeth $(2,23)$. Collectively, our study indicates that $\mathrm{BrSO}_{4}$-DAP at $1 \mathrm{mg} / \mathrm{mL}$ offered significantly superior residual antibacterial properties and comparable radiopacity to the commercially available radiopaque $\mathrm{Ca}(\mathrm{OH})_{2}$ medicament. Additionally, $\mathrm{ZrO}_{2}$-DAP at $1 \mathrm{mg} / \mathrm{mL}$ demonstrated comparable radiopacity and antibacterial characteristics. Further studies are warranted to determine the biocompatibility of the suggested radiopaque DAP medicaments.

\section{Acknowledgement}

The authors deny any conflicts of interest. 
References

1. Jenks DB, Ehrlich Y, Spolnik K, et al. Residual antibiofilm effects of various concentrations of double antibiotic paste used during regenerative endodontics after different application times. Arch Oral Biol 2016;70:88-93.

2. Jacobs JC, Troxel A, Ehrlich Y, et al. Antibacterial Effects of Antimicrobials Used in Regenerative Endodontics against Biofilm Bacteria Obtained from Mature and Immature Teeth with Necrotic Pulps. J Endod 2017;43:575-9.

3. Ruparel NB, Teixeira FB, Ferraz CC, et al. Direct effect of intracanal medicaments on survival of stem cells of the apical papilla. J Endod 2012;38:1372-5.

4. Althumairy RI, Teixeira FB, Diogenes A. Effect of dentin conditioning with intracanal medicaments on survival of stem cells of apical papilla. J Endod 2014;40:521-5.

5. Alghilan MA, Windsor $\amalg$, Palasuk J, et al. Attachment and proliferation of dental pulp stem cells on dentine treated with different regenerative endodontic protocols. Int Endod J 2017;50:667-75.

6. Kim KW, Yassen GH, Ehrlich Y, et al. The effects of radicular dentine treated with double antibiotic paste and ethylenediaminetetraacetic acid on the attachment and proliferation of dental pulp stem cells. Dent Traumatol 2015;31:374-9.

7. American Association of Endodontists. AAE Clinical Considerations for a Regenerative Procedure. Available at:

https://www.aae.org/uploadedfiles/publications and research/research/currentregenerativeendodonti cconsiderations.pdf Accessed october 20, 2017. 2017 [cited; Available from:

8. Yassen GH, Sabrah AH, Eckert GJ, et al. Effect of different endodontic regeneration protocols on wettability, roughness, and chemical composition of surface dentin. J Endod 2015;41:956-60.

9. Algarni AA, Yassen GH, Gregory RL. Inhibitory effect of gels loaded with a low concentration of antibiotics against biofilm formation by Enterococcus faecalis and Porphyromonas gingivalis. J Oral Sci 2015;57:213-8.

10. International Standards Organization. Dentistry: Root Canal Sealing Materials. ISO6876; 2012.

11. Alyas SM, Fischer BI, Ehrlich Y, et al. Direct and indirect antibacterial effects of various concentrations of triple antibiotic pastes loaded in a methylcellulose system. J Oral Sci 2016;58:575-82.

12. Sassone LM, Fidel RA, Faveri M, et al. A microbiological profile of unexposed and exposed pulp space of primary endodontic infections by checkerboard DNA-DNA hybridization. J Endod 2012;38:88993.

13. Stojicic S, Shen Y, Haapasalo M. Effect of the source of biofilm bacteria, level of biofilm maturation, and type of disinfecting agent on the susceptibility of biofilm bacteria to antibacterial agents. J Endod 2013;39:473-7.

14. Shen Y, Qian W, Chung C, et al. Evaluation of the effect of two chlorhexidine preparations on biofilm bacteria in vitro: a three-dimensional quantitative analysis. J Endod 2009;35:981-5.

15. Tagelsir A, Yassen GH, Gomez GF, et al. Effect of Antimicrobials Used in Regenerative Endodontic Procedures on 3-week-old Enterococcus faecalis Biofilm. J Endod 2016;42:258-62.

16. Sabrah AH, Yassen GH, Spolnik KJ, et al. Evaluation of Residual Antibacterial Effect of Human Radicular Dentin Treated with Triple and Double Antibiotic Pastes. J Endod 2015;41:1081-4. 
17. Murray PE, Lumley PJ, Ross HF, et al. Tooth slice organ culture for cytotoxicity assessment of dental materials. Biomaterials 2000;21:1711-21.

18. Li X, Yoshihara K, De Munck J, et al. Modified tricalcium silicate cement formulations with added zirconium oxide. Clin Oral Investig 2017;21:895-905.

19. Mozynska J, Metlerski M, Lipski M, et al. Tooth Discoloration Induced by Different Calcium Silicate-based Cements: A Systematic Review of In Vitro Studies. J Endod 2017;43:1593-601.

20. Lenherr P, Allgayer N, Weiger R, et al. Tooth discoloration induced by endodontic materials: a laboratory study. Int Endod J 2012;45:942-9.

21. Zandi $\mathrm{H}$, Rodrigues RC, Kristoffersen AK, et al. Antibacterial Effectiveness of 2 Root Canal Irrigants in Root-filled Teeth with Infection: A Randomized Clinical Trial. J Endod 2016;42:1307-13.

22. Peters LB, van Winkelhoff AJ, Buijs JF, et al. Effects of instrumentation, irrigation and dressing with calcium hydroxide on infection in pulpless teeth with periapical bone lesions. Int Endod J 2002;35:13-21.

23. Cvek M, Nord CE, Hollender L. Antimicrobial effect of root canal debridement in teeth with immature root. A clinical and microbiologic study. Odontol Revy 1976;27:1-10. 


\begin{tabular}{|c|c|c|c|c|}
\hline Type of treatment & $\begin{array}{c}\text { Direct } \\
\text { antibacterial } \\
\text { effects } \\
\text { Mean } \log _{10} \text { (SE) }\end{array}$ & $\begin{array}{l}\text { Number of } \\
\text { positive } \\
\text { samples }\end{array}$ & $\begin{array}{c}\text { Residual } \\
\text { antibacterial } \\
\text { effects } \\
\text { Mean } \log _{10} \text { (SE) }\end{array}$ & $\begin{array}{c}\text { Number of } \\
\text { positive } \\
\text { samples }\end{array}$ \\
\hline $\begin{array}{l}\mathrm{BrSO}_{4}-\mathrm{DAP} \\
25 \mathrm{mg} / \mathrm{mL}\end{array}$ & $0.00(0) A$ & $0 / 7$ & $0.00(0) A$ & $0 / 7$ \\
\hline $\begin{array}{l}\mathrm{BrSO}_{4}-\mathrm{DAP} \\
10 \mathrm{mg} / \mathrm{mL}\end{array}$ & $0.00(0) \mathrm{A}$ & $0 / 7$ & $0.00(0) \mathrm{A}$ & $0 / 7$ \\
\hline $\mathrm{BrSO}_{4}$-DAP $1 \mathrm{mg} / \mathrm{mL}$ & $0.00(0) A$ & $0 / 7$ & $0.00(0) \mathrm{A}$ & $0 / 7$ \\
\hline $\mathrm{ZrO}_{2}$-DAP $25 \mathrm{mg} / \mathrm{mL}$ & $0.00(0) \mathrm{A}$ & $0 / 7$ & $0.00(0) \mathrm{A}$ & $0 / 7$ \\
\hline $\mathrm{ZrO}_{2}-\mathrm{DAP} 10 \mathrm{mg} / \mathrm{mL}$ & $0.00(0) \mathrm{A}$ & $0 / 7$ & $0.00(0) \mathrm{A}$ & $0 / 7$ \\
\hline $\mathrm{ZrO}_{2}$-DAP $1 \mathrm{mg} / \mathrm{mL}$ & 1.66 (0.61)B & $4 / 7$ & $5.26(0.20) B$ & $7 / 7$ \\
\hline $\mathrm{Ca}(\mathrm{OH})_{2}$ & $0.00(0) \mathrm{A}$ & $0 / 7$ & $5.48(0.56) \mathrm{B}$ & $7 / 7$ \\
\hline $\mathrm{BrSO}_{4}$-Placebo & $6.18(0.06) \mathrm{C}$ & $7 / 7$ & $5.33(0.27) B$ & $7 / 7$ \\
\hline $\mathrm{ZrO}_{2}$-Placebo & $6.17(0.07) C$ & $7 / 7$ & $5.30(0.33) \mathrm{B}$ & $7 / 7$ \\
\hline Positive control & $6.20(0.03) \mathrm{C}$ & $7 / 7$ & $5.55(0.25) \mathrm{B}$ & $7 / 7$ \\
\hline Negative control & $0.00(0) A$ & $0 / 7$ & $0.00(0) A$ & $0 / 7$ \\
\hline
\end{tabular}

Table 1. The direct and residual antibacterial effects of the different radiopaque antimicrobials against bacterial biofilms from immature teeth with pulpal necrosis represented as the mean (SE) of the $\log \mathrm{CFU} / \mathrm{mL}$

Different upper-case letters indicate significant differences between the different types of treatment within each experiment. 
Figure 1. The radiopacity of different radiopaque antibacterial medicaments represented as the mean $( \pm \mathrm{SE})$ of $\mathrm{mm} \mathrm{Al}$.

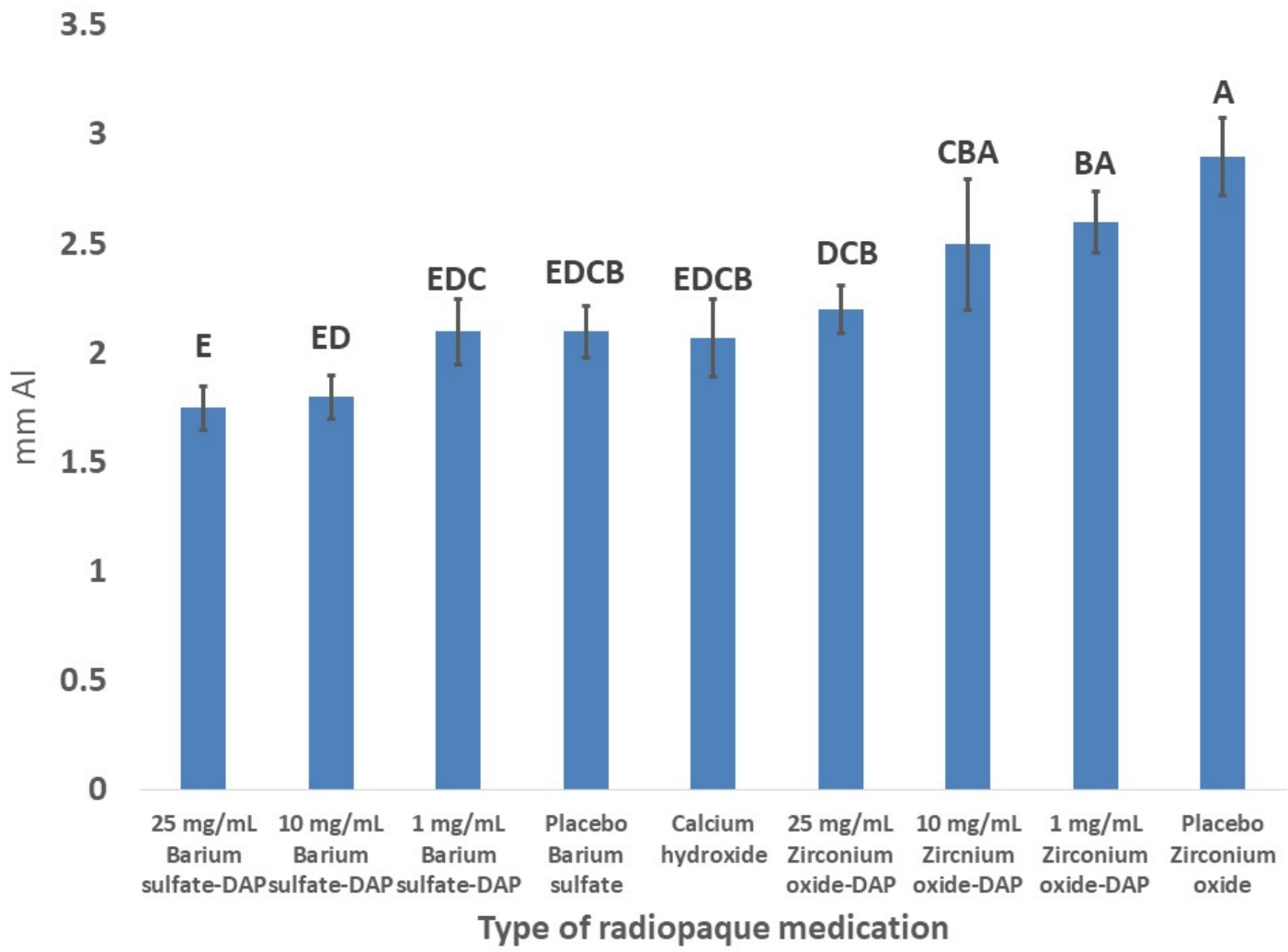

Figure 2. Scanning electron microscopic images under low (A) and high (B) magnifications of established 3-week old bacterial biofilm on dentin formed by bacteria obtained from an infected root canal of an immature tooth with necrotic pulp. 

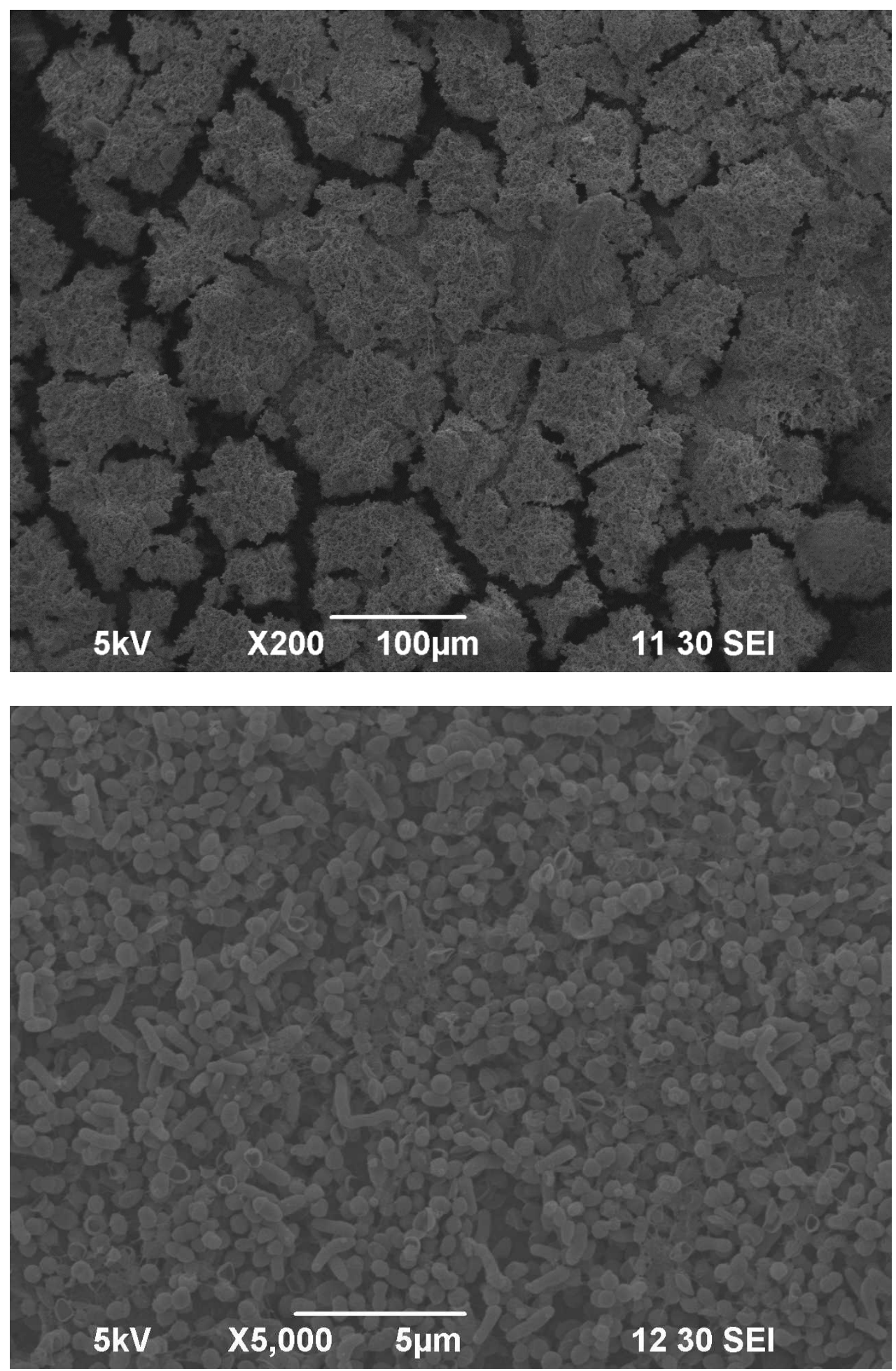